\title{
Management fees: Determinants and influence of legal limits. Evidence from Spanish pension funds*
}

\author{
Las comisiones de gestión: factores determinantes e influencia \\ de los límites legales. Evidencia de fondos de pensiones españoles
}

\author{
Mercedes AldA** \\ LUIS FERRUZ***
}

\begin{abstract}
Pension funds in Spain have become of considerable importance in recent years. In fact, many studies have focused on fund performance and the adverse impact offees, although little work has been done on analysis of the determinants offees. Even though fees are restricted by legal limits in many countries, traditional models do not take these limits into account, and results could be biased; therefore, censored models (such as Tobit or CLAD) may provide a better fit. In this work, we study the determinants of management fees in Spanish equity pension funds. We find a better fit in the CLAD model, which provides unbiased and consistent estimators. Additionally, older and larger pension funds charge greater management fees and these fees increase with low volatility. However, fund returns and market returns barely affect such fees.
\end{abstract}

Key words: Pension funds, management fees, determinants, censored models.

JEL Classification: $G 23, G 10$.

\section{Resumen}

Los fondos de pensiones en España han alcanzado una importancia considerable en los últimos años. De hecho, muchos trabajos estudian su desempeño y el impacto negativo de las comisiones; sin embargo, pocos analizan los factores que influyen en las comisiones.

Asimismo, en muchos países las comisiones están restringidas por límites legales. No obstante, los modelos tradicionales no tienen en cuenta estos límites, y

* The authors want to express our gratitude to an anonymous referee for all valuable and constructive comments, which have contributed greatly to improve the quality of our paper. Additionally, we would also like to thank the Government of Aragon for the funding that we receive as a Public and Official Research Group.

**malda@unizar.es

***iferruz@unizar.es 
los resultados podrían estar sesgados; por ello, los modelos censurados (como Tobit o CLAD) podrían proporcionar un mejor ajuste.

En este trabajo estudiamos los factores que influyen en las comisiones de gestión de fondos de pensiones españoles de renta variable. El modelo que proporciona un mejor ajuste es el CLAD, ya que proporciona estimadores insesgados y consistentes. Adicionalmente, los fondos de pensiones más antiguos y más grandes cargan más comisiones de gestión. Asimismo, estas comisiones aumentan cuando hay poca volatilidad; sin embargo, la rentabilidad del fondo y la rentabilidad del mercado apenas les afectan.

Palabras clave: Fondos de pensiones, comisiones de gestión, factores determinantes, modelos censurados.

Clasificación JEL: G23, G10.

\section{INTRODUCTION}

In recent years, pension funds have experienced significant international development. At the end of 2011, the total assets invested worldwide amounted to more than 16 billion Euros. This development has stimulated the study of pension fund performance in order to explain their role in financial markets.

In Spain, pension funds are second only to mutual funds as investment products, but despite the fact that all pension funds are voluntary, private, and appeared relatively lately (in 1987), the investment total increased from $€ 152$ million in 1988 to over $€ 86.536$ billion in 2012, according to INVERCO (the Spanish Association of Investment and Pension Funds).

Pension funds are long-term savings products that are managed by experts, and investors expect to enjoy certain financial advantages (professional management, security, and information); nonetheless, pension funds charge several levels of fee (management, custodial, administration, accounting, registration...) for these services.

In general, fees negatively affect performance, and many authors have studied this relationship (Ippolito and Turner, 1987; Brown et al., 1992; Dellva and Olson, 1998; Blake et al., 1999; Kumples and McCrae, 1999; and Otten and Bams, 2002). However, few studies have focused on the determinants of fees, which constitutes the primary interest of our analysis.

Certain fees are regulated by legislation; for example, Spanish legislation sets maximum legal limits for management and custodial fees, specifically, $2 \%$ and $0.5 \%$ per annum of the account value, respectively (Legislative Decree 1/2002 and Royal Decree 304/2004).

Despite this, it is remarkable that most studies use traditional estimation models, which do not consider these limits, so results could be biased, providing inconsistent estimators. In order to solve this problem, censored models could be applied, analyzing whether they provide a better fit.

In this work, we study the determinants of management fees for Spanish equity pension funds, with European, global and domestic investment goals, from October 1997 to September 2012. Additionally, we examine the impact 
of legal limits on management fees, applying two different censored models: a Tobit model and a Censored Least Absolute Deviation (CLAD) model.

The rest of the paper is organised as follows: in Section Two, we undertake a literature review. Section Three describes the Spanish pension fund market and the data used. Section Four presents our methodology. Section Five contains our empirical results, and Section Six shows our main conclusions.

\section{Literature Review}

The financial literature on pension funds has traditionally focused on the fee-performance relationship, and several studies have shown the negative impact of fees (Blake et al., 2002; Dobronogov and Murthi, 2005; Martí and Matallín, 2008; or Sy and Liu, 2010).

However, and to the best of our knowledge, there are no studies that analyze the determinants of pension fund fees, while we find several mutual fund studies of this topic. Although pension funds and mutual funds present some differences, both are investment products and thus we consider that the determinants of fees in mutual funds could be equally important in a study of pension funds.

The empirical evidence on mutual fund fees displays different determinants. For example, Gil-Bazo and Martínez (2004) examine Spanish mutual fund fees and find management companies owned by banks and savings banks charge higher management fees. Cullinan and Bline (2005) examine custodial fees in US mutual funds and find that fund size is the major determinant. Khorana et al. (2009) examine mutual fund fees in eighteen countries, discovering that the differences in fees are due to investment objective, type of fund, investor clientele, and fund age.

In relation to the influence of legal limits and censored models, we find a sparse literature. Martí et al. (2007) study their determinants in the cross-section data of personal pension plans in Spain, using Tobit and CLAD models, concluding that censored models provide better estimators. Results also show that management company, plan results, management style, and mean investment of each investor all influence management fees.

We should note that the analysis of Martí et al. (2007) presents a shortcoming, since the authors consider cross-section data; for this reason, in our work we attempt to overcome the problem by applying censored models to a broad period.

The literature review reveals that most pension fund studies analyze the influence of fees on performance, but few examine their determinants, or consider legal limits. Consequently, this paper's intent is to fill this gap, providing a better approach and considering the legal limits.

\section{Spanish Pension Fund Market and Data}

\subsection{Spanish pension fund market}

In Spain, pension plans and pension funds appeared in 1987, with the Act $1307 / 1988$. These products constitute a private long-term savings and insurance system, designed to ensure available capital at retirement, thus forming a system complementary to the existing public pension system, but not substituting for it. 
Specifically, pension plans are voluntary and private welfare institutions, where investors place their investment. However, pension plans cannot perform the investment by themselves, so a pension fund must be established; in other words, a pension fund is where pension plans are invested.

As a result, a pension fund is constituted by a set of pension plans with similar characteristics, and managers are responsible for managing pension funds (they do not manage pension plans individually). Furthermore, fees are charged at the fund level; for these reasons, we focus our study on the analysis of pension funds.

Despite the fact that these products are voluntary, and appeared late, the investment has evolved positively over time, as Table 1 illustrates.

TABLE 1

EVOLUTION OF INVESTMENTS IN SPANISH PENSION FUNDS

\begin{tabular}{|cc|}
\hline Year & $\begin{array}{c}\text { Investment } \\
\text { (in million of Euros) }\end{array}$ \\
\hline 1988 & 152.837 \\
1989 & 511.425 \\
1990 & 3214.471 \\
1991 & 4890.820 \\
1992 & 6604.263 \\
1993 & 8608.958 \\
1994 & 10407.510 \\
1995 & 12822.281 \\
1996 & 17441.311 \\
1997 & 21910.173 \\
1998 & 27161.041 \\
1999 & 31663.620 \\
2000 & 37859.781 \\
2001 & 43829.160 \\
2002 & 48322.288 \\
2003 & 55912.090 \\
2004 & 63004.483 \\
2005 & 72909.694 \\
2006 & 81263.344 \\
2007 & 85834.957 \\
2008 & 78406.588 \\
2009 & 85003.996 \\
2010 & 84750.244 \\
2011 & 83147.626 \\
2012 & 86536.444 \\
\hline
\end{tabular}

Table 1 shows the investment evolution of the Spanish pension funds from 1988 to 2012. The data is shown in million of Euros. Source: INVERCO. 
This Table shows a steady increase from 1988 to 2007. However, in 2008 the level of investment decreased significantly, affected by the economic and financial crisis. Nonetheless, it recovered slightly during 2009 and 2010, and although it suffered a fall in 2011, it attained the peak amount in 2012, totalling more $€ 86.536$ billion.

Finally, we should note that, although pension funds are private, Spanish legislation establishes maximum limits on management and custodial fees; specifically, $2 \%$ and $0.5 \%$ of the account value, respectively (article 84 of the RD 304/2004).

\subsection{Data}

We obtain our data from Thomsom Reuters. The data comprises a total of 176 Spanish equity pension funds with European (87), global (65), and domestic (24) investment locations, respectively.

For each fund, we have monthly return, AUM (assets under management), and management fees, from October 1997 to September 2012. We also have information on the type of management company.

We select equity pension funds because these are more directly affected by market fluctuations. In addition, we choose equity pension funds with European, global, and domestic investment locations since these are the three main investment universes of Spanish pension funds. Finally, we focus on management fees, since these fees are the most significant (in amount) compared to other existing expenses, and because of data availability problems.

The market benchmarks used are the MSCI-World, the MSCI-Europe, and the MSCI-Spain 1 , given the three investment universes analyzed. We should clarify that, when we analyze the full sample, we use the MSCI-World index.

The main statistics of the sample are displayed in Table 2, which is divided into four panels and shows the mean, median, standard deviation, minimum, and maximum of the variables studied: management fees, fund returns, fund volatility, fund age, fund size, and market return for all pension funds (panel A), European pension funds (panel B), global pension funds (panel C), and domestic equity pension funds (panel D).

In panel $\mathrm{A}$, we observe mean management fees of $1.6 \%$ and positive fund returns $(0.04 \%)$, although it is noteworthy that pension funds do not beat the market $(0.2 \%)$.

By investment location, management fees are, on average, higher in domestic equity pension funds ( $1.7 \%$ in panel $\mathrm{D})$; however, these funds present the best returns $(0.1 \%)$. The volatility is similar in all panels. In relation to age, pension funds are, on average, 8.6 years old, although European pension funds are the oldest (111.39 months), and domestic funds are the youngest (83.92 months).

Finally, pension funds present a mean fund size of $€ 28.3$ million (panel A), with domestic funds being the largest (the mean is $€ 44.6$ million in panel D).

To ensure the consistency of the analysis, we analyze the correlations between the variables studied. Table 3 collects this information.

1 Data obtained from MSCI: www.msci.com 
TABLE 2

SUMMARY STATISTICS

\begin{tabular}{|c|c|c|c|c|}
\hline & Mean & Std. Dev. & Min & Max \\
\hline \multicolumn{5}{|c|}{ Panel A: All equity pension funds } \\
\hline Management fees & 0.016 & 0.008 & 0.000 & 0.02 \\
\hline Net return & 0.0004 & 0.049 & -0.994 & 0.333 \\
\hline Volatility & 0.038 & 0.021 & 0.000 & 0.390 \\
\hline Age & 104.710 & 44.732 & $10^{-5}$ & 180 \\
\hline Size & 28.300 & 59.500 & 2 & 710 \\
\hline Market return & 0.002 & 0.044 & -0.165 & 0.100 \\
\hline \multicolumn{5}{|c|}{ Panel B: European equity pension funds } \\
\hline Management fees & 0.016 & 0.008 & 0.000 & 0.02 \\
\hline Net return & 0.0002 & 0.049 & -0.254 & 0.333 \\
\hline Volatility & 0.038 & 0.020 & 0.000 & 0.149 \\
\hline Age & 111.391 & 39.881 & 22 & 180 \\
\hline Size & 23.200 & 45.400 & $10^{-5}$ & 421 \\
\hline Market return & 0.002 & 0.049 & -0.143 & 0.120 \\
\hline \multicolumn{5}{|c|}{ Panel C: Global equity pension funds } \\
\hline Management fees & 0.015 & 0.008 & 0.000 & 0.02 \\
\hline Net return & 0.0005 & 0.047 & -0.994 & 0.303 \\
\hline Volatility & 0.035 & 0.021 & 0.000 & 0.390 \\
\hline Age & 103.446 & 44.527 & 9 & 180 \\
\hline Size & 31.800 & 78.700 & 0.005 & 710 \\
\hline Market return & 0.002 & 0.044 & -0.165 & 0.100 \\
\hline \multicolumn{5}{|c|}{ Panel D: Domestic equity pension funds } \\
\hline Management fees & 0.017 & 0.007 & 0.000 & 0.02 \\
\hline Net return & 0.001 & 0.058 & -0.263 & 0.232 \\
\hline Volatility & 0.046 & 0.022 & 0.000 & 0.117 \\
\hline Age & 83.917 & 54.232 & 2 & 180 \\
\hline Size & 44.600 & 68.200 & 0.0001 & 299 \\
\hline Market return & 0.003 & 0.066 & -0.224 & 0.175 \\
\hline
\end{tabular}

Table 2 shows summary statistics (mean, standard deviation, minimum and maximum) of the variables studied: management fees, net returns, volatility (expressed as the standard deviation of the fund returns), fund age (in months), fund size (in million of Euros) and market returns during the period October 1997 to September 2012 for all Spanish equity pension funds studied (panel A), and for the Spanish equity pension funds with European (panel B), global (panel C) and domestic (panel D) investment locations. 
TABLE 3

CORRELATION BETWEEN VARIABLES

\begin{tabular}{|c|c|c|c|c|c|c|}
\hline & Management fees & Fund return & Volatility & Age & Size & Market return \\
\hline Management fees & 1 & & & & & \\
\hline Fund return & 0.003 & 1 & & & & \\
\hline Volatility & $0.0364 * *$ & -0.012 & 1 & & & \\
\hline Age & $0.5468 * *$ & 0.007 & $0.0751 * *$ & 1 & & \\
\hline Size & $-0.0804 * *$ & 0.007 & 0.004 & $0.0811 * *$ & 1 & \\
\hline Market return & 0.000 & $0.8253^{*}$ & -0.007 & 0.000 & 0.003 & 1 \\
\hline
\end{tabular}

Table 3 represents the correlation matrix between the variables analyzed (management fees, fund returns, fund volatility, fund age, fund size and market return) for all pension funds studied.

** Significant at the 5\% level.

Table 3 shows the correlations considering all pension funds studied. This Table does not display great significance levels, and although two correlations are significantly large ( 0.54 between age and management fees and 0.82 between market returns and pension fund returns); in general, we assume there will be no further multi-collinearity problems. Finally, we note the negative correlation between management fees and size, although it is not large.

We do not display the correlation matrix for the pension funds differentiating by investment location, but the conclusions are quite similar ${ }^{2}$.

\section{Methodology}

\subsection{Fee models}

Prior studies of mutual and pension funds (Ferris and Chance, 1987; Tufano and Sevick, 1997; Latzko, 1999; Malhotra and McLeod, 1997; Luo, 2002; Deli, 2002; and Golec, 2003) reveal that fees are influenced by several factors, the main ones being: returns, volatility, size, age, and management group.

In the first place, we develop a model from a risk-return perspective, introducing certain control variables: market return, fund age, and fund size

$$
f_{i t}=\alpha_{i}+\beta_{1} r_{i t-1}+\beta_{2} r_{m t-1}+\beta_{3} \sigma_{i t-1}+\beta_{4} A_{i t-1}+\beta_{5} S_{i t-1}+\varepsilon_{t}
$$

2 These results are available upon request. 
Where: $f_{i t}$ are the management fees; $\alpha_{i}$ is the intercept of the pension fund $i ; r_{i t-1}$ are the net returns of fund $i$ in the period $t-1 ; r_{m t-1}$ are the market returns in the period $t-1 ; \sigma_{i t-1}$ is the standard deviation of fund $i$ at time $t-1 ; A_{i t-1}$ is the natural logarithm of the fund age (in months) at time $t-1, S_{i t-1}$ is the natural logarithm of the AUM (Assets Under Management) of fund $i$ at time $t-1$; and $\varepsilon_{t}$ are the error terms.

Second, we consider the type of management company, since Martí and Matallín (2008) demonstrate the influence of the management company type on fees. We divide our sample into three types of management company: banks, savings banks, and insurance companies, and we take into account the three investment locations (Europe, global, and domestic) of pension funds, obtaining model (2):

$$
f_{i t}=\alpha_{i}+\beta_{1} r_{i t-1}+\beta_{2} r_{m t-1}+\beta_{3} \sigma_{i t-1}+\beta_{4} A_{i t-1}+\beta_{5} S_{i t-1}+\sum_{j=6}^{8} \beta_{i} M C_{i t}+\sum_{j=9}^{11} \beta_{j} L_{j t}+\varepsilon_{t}
$$

Where: $f_{i t}$ are the management fees; $\alpha_{i}$ is the intercept of fund $i ; r_{i t-1}$ are the fund returns in the period $t-1 ; r_{m t-1}$ are the market returns in the period $t-1$, $\sigma_{i t-1}$ is the standard deviation of fund $i$ at time $t-1 ; A_{i t-1}$ is the natural logarithm of the fund age (in months) at time $t-1$, and $S_{i t-1}$ is the natural logarithm of the AUM (Assets Under Management) of fund $i$ at time $t-1 ; M C_{j t}$ are three dummy variables that consider the type of management company (banks, savings banks, and insurance companies) at time $t ; L_{j t}$ are three dummy variables that consider the investment location (European, global, and domestic) of pension funds at time $t$, and $\varepsilon_{t}$ are the error terms.

\subsection{Censored models}

Spanish pension funds cannot apply management fees greater than $2 \%$ of fund assets, according to current legislation (article 84 of RD 304/2004); as a consequence, we should consider that fees are the dependent variable, which is a censored variable.

For that reason, Ordinary Least Squared (OLS) estimations may produce inconsistent estimators (Maddala and Nelson, 1975; Loucks, 1994; Chou and Cebula, 1996; Greene, 2000 and Martí et al., 2007). In order to solve this, we apply censored models that include these limits; in particular, we employ Tobit and CLAD models.

\subsubsection{Tobit model}

The Tobit model is proposed by Tobin (1958), and includes maximum and minimum limits to the censored variable. Considering model (1), the corresponding Tobit model is: 


$$
\begin{aligned}
& f_{i t}=\alpha_{i}+\beta_{1} r_{i t-1}+\beta_{2} r_{m t-1}+\beta_{3} \sigma_{i t-1}+\beta_{4} A_{i t-1}+\beta_{5} S_{i t-1}+\varepsilon_{t} \quad \text { if } \quad \underline{f}<f_{i t}<\bar{f} \\
& \text { (3) } f_{i t}=\bar{f} \\
& \text { if } \quad f_{i t}>\bar{f} \\
& f_{i t}=\underline{f} \\
& \text { if } \quad f_{i t}<\underline{f}
\end{aligned}
$$

Where: $f_{i t}$ is the management fee, and $\bar{f}$ and $f$ are the maximum and minimum legal fees. The Spanish legislation does not establish a legal minimum, so we only include the maximum limit ( $2 \%)$.

Nonetheless, this model assumes homoskedasticity and a normal distribution of residuals. Arabmazar and Schmidt (1981) and Greene (2000) prove that whether the assumptions of homoskedasticity and normality fail, the Tobit model produces inconsistent and biased estimators.

In order to test homoskedasticity and normality, we apply the likelihood ratio test of Petersen and Waldman (1981) and the Jarque-Bera test, respectively.

\subsubsection{CLAD model}

The CLAD (censored least absolute deviations) model, proposed by Powell (1984), considers only the maximum limit of the dependent variable. Moreover, estimators are robust in the presence of heteroskedasticity and non-normality.

The CLAD model is collected in the expression (4):

$$
f_{i t}=\alpha_{i}+\beta_{1} r_{i t-1}+\beta_{2} r_{m t-1}+\beta_{3} \sigma_{i t-1}+\beta_{4} A_{i t-1}+\beta_{5} S_{i t-1}+\varepsilon_{t} \text { if } \quad \alpha_{i}+\beta_{1} r_{i t-1}+\beta_{2} r_{m t-1}+\beta_{3} \sigma_{i t-1}+\beta_{4} A_{i t-1}+\beta_{5} S_{i t-1}+\varepsilon_{t} \leq \bar{f}
$$

$f_{i t}=\bar{f}$

$$
\text { if } \alpha_{i}+\beta_{1} r_{i t-1}+\beta_{2} r_{m t-1}+\beta_{3} \sigma_{i t-1}+\beta_{4} A_{i t-1}+\beta_{5} S_{i t-1}+\varepsilon_{t}>f
$$

Where: $f_{i t}$ are the management fees and $\bar{f}$ is the legal maximum management fee.

\subsubsection{Robustness test}

The Tobit model does not provide robust and consistent estimators in the presence of heteroskedasticity and non-normality; however, the CLAD estimator is robust and consistent. In order to examine the robustness of the Tobit and CLAD models, we apply the Hausman test, described by Melenberg and van Soest (1996) and Greene (2000).

This test allows us to compare two models when we have a consistent and efficient estimator under the null hypothesis, but inconsistent under the alternative (Tobit estimator), and another consistent estimator under both hypotheses, but inefficient under the null hypothesis (CLAD estimator).

To apply the Hausman test, we build the Wald statistic, using the estimations of both models. This statistic is distributed as a chi-squared with $\mathrm{R}$ degrees of freedom: 
(5)
$W=\left(\hat{\beta}_{T o b i t}-\hat{\beta}_{C L A D}\right)^{\prime}\left[\operatorname{Var}\left(\hat{\beta}_{\text {Tobit }}-\hat{\beta}_{C L A D}\right)\right]^{-1}\left(\hat{\beta}_{\text {Tobit }}-\hat{\beta}_{C L A D}\right) \sim \chi^{2}(R)$

Where R represents the range of $\operatorname{Var}\left(\hat{\beta}_{\text {Tobit }}-\hat{\beta}_{C L A D}\right)$.

\section{Results}

\subsection{Determinants of management fees with OLS estimation}

In this section, we estimate models (1) and (2) using the Ordinary Least Squared estimation; that is to say, we do not consider the legal limit.

Table 4 presents the results obtained from the estimation of model (1). The table is divided into four panels; panel A shows the results for all equity pension funds, and panels B, C and D display the results for the equity pension funds with European, global, and domestic investment goals, respectively.

Panel A shows that management fees are not influenced by past fund return and market return, indicating that the evolution of market return does not affect the fee level. Nonetheless, management fees present an inverse relationship to fund volatility (management fees decrease with higher volatility) and a positive relationship to the age and size of the pension fund (fees increase when the pension fund is older and larger).

Panel B shows that fund returns and volatility inversely affect management fees, but market return, age, and size present a positive relationship.

Panel C displays different results: management fees present an inverse relationship to market returns, volatility, and size, but a positive relationship to fund return and age.

Finally, panel D exhibits an absence of influence on fund return, market return, and age, but positive relationships to volatility and size.

The evidence of this Table is diverse, but we can conclude that mature and larger pension funds charge higher management fees, demonstrating the existence of learning economies but absence of economies of scale. These fees also increase when volatility decreases.

The influence of fund return and market return is not clear, so we can conclude that pension funds charge fees according to fund characteristics; in fact, fund returns have a negative influence on European fund fees, but a positive influence on global fund fees. Market returns present the opposite behavior in these funds. Finally, these two variables are not significant for fees of domestic funds.

We then estimate model (2). Table 5 illustrates the results.

The Table is divided into four panels. Panel A collects the results of all pension funds, where we observe different results in relation to Table 4; specifically, an inverse relationship with fund returns, but a positive relationship with market return, volatility, age, and size. The dummy variables for the type of the management company are significantly positive and the magnitudes are similar; in other words, different companies charge similar management fees. We do not find different fees associated with banks, savings banks, or insurance companies. Finally, the investment location does not influence fees $\left(\beta_{9}, \beta_{10}, \beta_{11}\right.$ are not significant). 


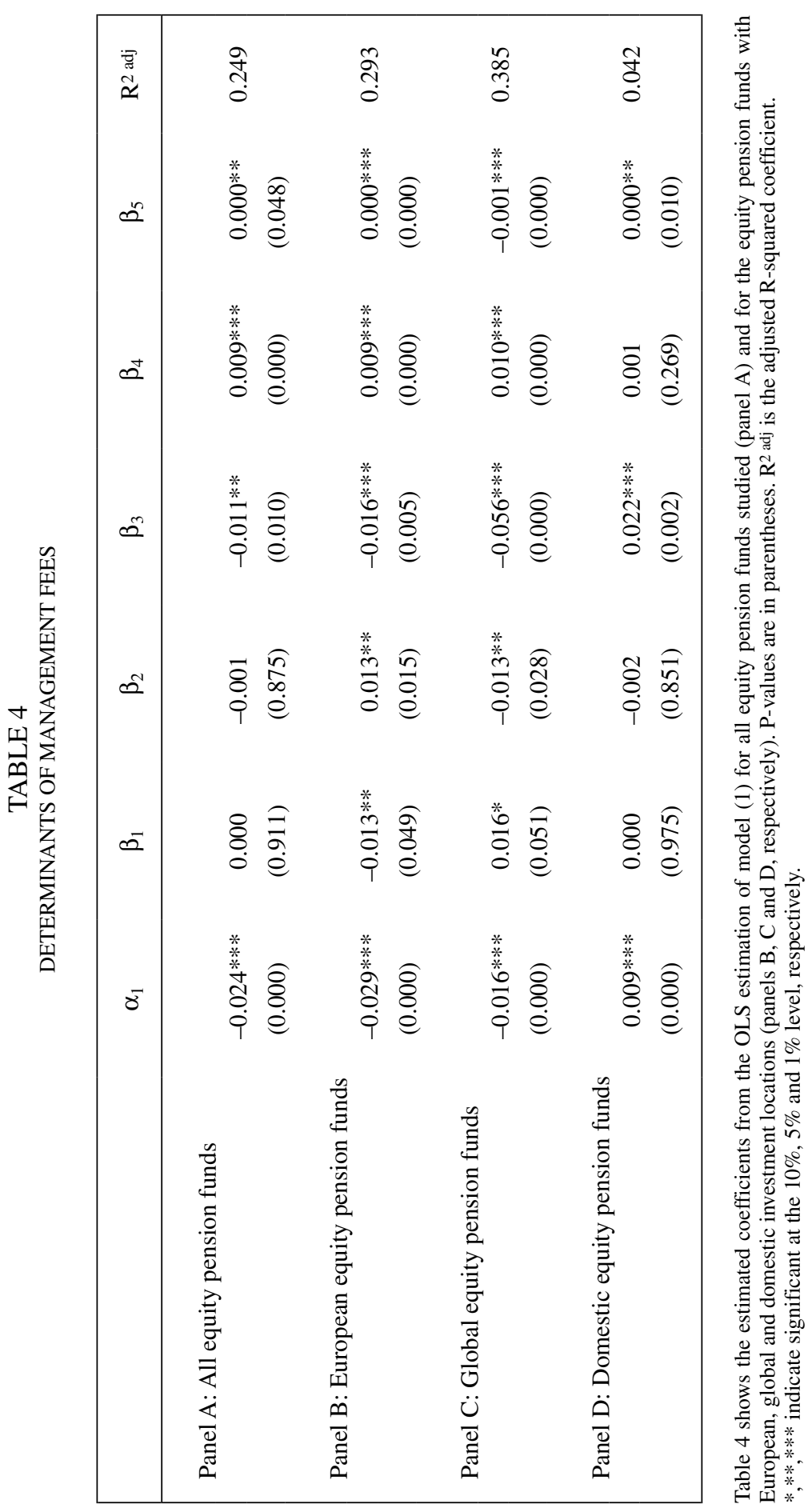


Although the investment location does not influence fees at the aggregate level, we want to see whether the relationship between these factors and fees is different when we consider the investment locations separately; to do this, we divide the pension funds according to the three investment locations studied. These results are collected in panels B, C and D.

We find different evidence among panels. The management fees in European funds (panel B) display the same behavior as the whole sample: a negative relationship to fund return but a positive relationship to the rest of the variables. Global pension fund fees (panel C) show different results: an inverse relationship to fund size, but a positive relationship to age and the three types of management companies. On the other hand, fund return, market return, and volatility have no influence. Finally, panel D reveals that only volatility and management company coefficients are significantly positive.

These panels also reveal significantly positive management company coefficients, so all management companies present the same patterns: they charge similar fees and it is irrelevant whether the management company is a bank, a savings bank, or an insurance company; as a result, Table 4 appears to present more consistent results.

\subsection{Determinants of management fees by periods}

We consider it important to analyze whether determinants of management fees are different before and after the current economic crisis. We estimate model (1) dividing the sample into two periods: from October 1997 to December 2007, and from January 2008 to September 2012. We choose this intersection point since, as we observe in Table 1 , the positive evolution of pension funds is affected only after 2008. Table 6 displays the results.

Comparing Table 4 and Table 6, panel A reflects fund return and presents an inverse relationship to management fees only after the economic crisis. The remaining variables do not change.

Panel B shows that management fees of European funds are affected by market return only in the pre-crisis period, and are independent of the market after 2008.

Panel $\mathrm{C}$ shows that fund returns and market returns are not significant when we divide the sample, although they are significant when we consider the whole sample.

Panel D shows two differences with respect to Table 4 in the period 19972007; specifically, management fees present a negative relationship to market return, and the fund size coefficient is not significant.

Subsequently, we only find significant differences in the influence of market returns; indeed, market returns only influence management in the pre-crisis period (1997-2007).

\subsection{Determinants of management fees with censored models}

The models applied previously do not consider the legal limit of management fees, so results could be biased. We re-estimate model (1) with the two censored models explained in the methodology (Tobit and CLAD). 


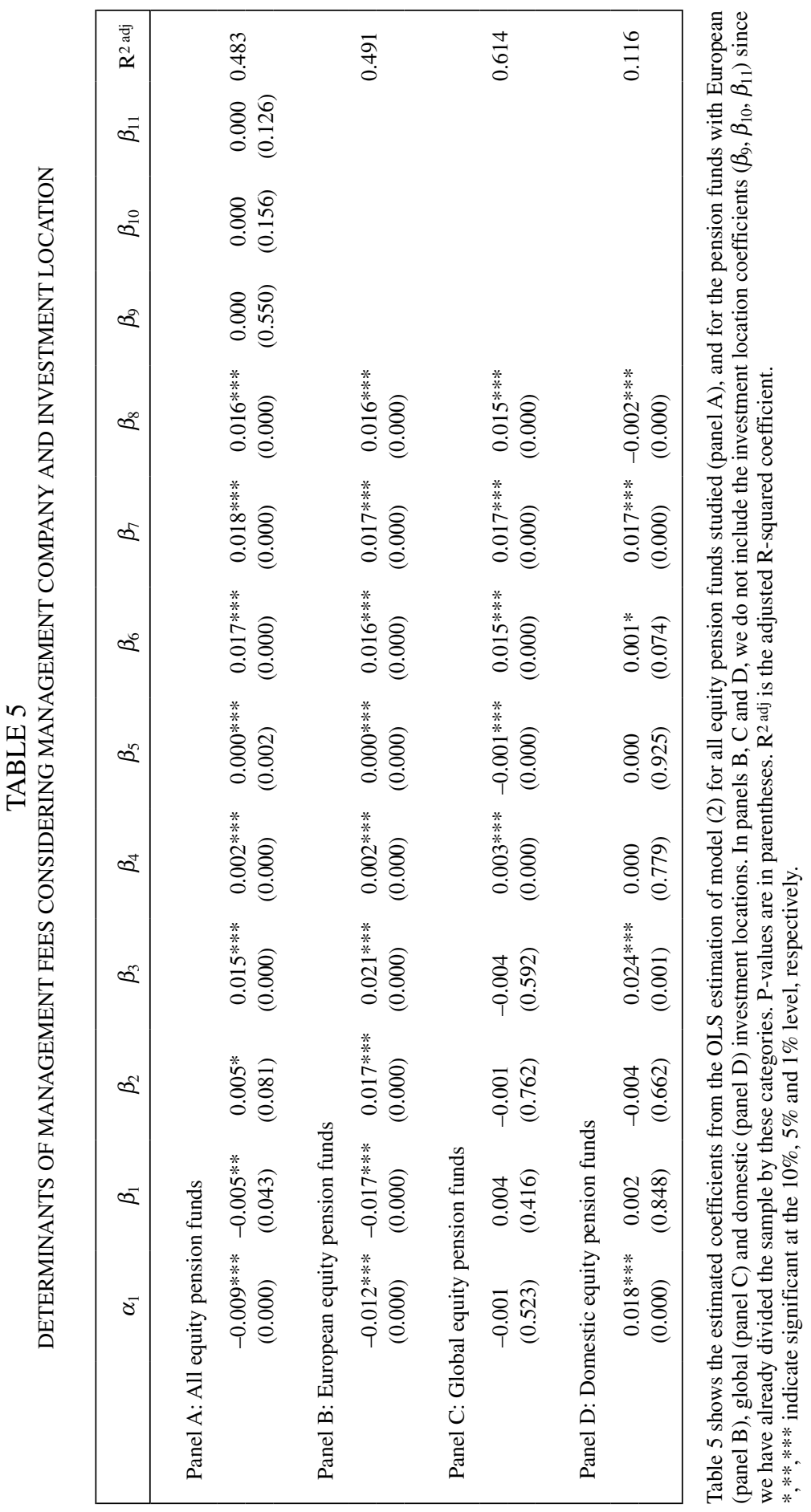




\subsubsection{Tobit estimation}

First, we estimate the Tobit model. Table 7 collects the results of model (3), taking into account the maximum level $(\bar{f})$ of $2 \%$. We maintain this limit throughout the period of study because the regulation has not changed since 1988 .

Table 7 provides some results analogous to Table 4, although significant coefficients are higher than in the OLS estimation. We observe that management fees increase when volatility decreases, and older funds charge more fees. However, the influence of size is not clear. The return and the market return are again significant in European and global pension funds, although their influence is contrary.

We also apply the Tobit estimation, dividing the sample into two periods (1997-2007 and 2008-2012), although we do not report these results ${ }^{3}$. With respect to Table 7 , focusing on all pension funds, fund returns turn out to be significantly negative in the period from 2008 to 2012, and the size factor influences positively in the first period, but negatively in the second. Second, in the European pension funds, fund return and market return do not influence management fees in the second period. In global pension funds, fund return and market return do not influence fees in the first period.

We observe again the major changes in returns, although the pattern between periods is not clear.

\subsubsection{Robustness tests of Tobit model}

In order to check the suitability of the Tobit model, we test the null hypotheses of homoskedasticity and normality of the residuals.

To test the homoskedasticity, we display the likelihood ratios in Table 7. All statistics are asymptotically distributed with a chi-square of 5 degrees of freedom. The sample values of the different panels (1683.45, 1207.85, 687.98 and 36.12 in panels A, B, C and D, respectively) exceed the critical value (15.086) at the $1 \%$ significance level, which leads us to reject the null hypothesis of homoskedasticity.

The normality test is carried out with the Jarque-Bera test for each pension fund sample. All Jarque-Bera tests present p-values equal to zero, so we also reject the null hypothesis of normality.

The evidence of heteroskedasticity and non-normality of the residuals demonstrates inconsistent Tobit estimators, leading to underestimation or overestimation of certain variables. Consequently, we should estimate the CLAD model.

\subsubsection{CLAD estimation}

Table 8 provides the result of the CLAD model (4), providing different results from OLS and Tobit models.

Comparing panels of Table 8 with Tables 4 and 7, panel A of Table 8 shows the same results as the OLS estimation and, with respect to the Tobit model, the size factor is significant. In panel B, market returns turn out to be insignificant. In panel $\mathrm{C}$, fund return and market return do not influence fees, but in panel D,

3 These results are available upon request. 


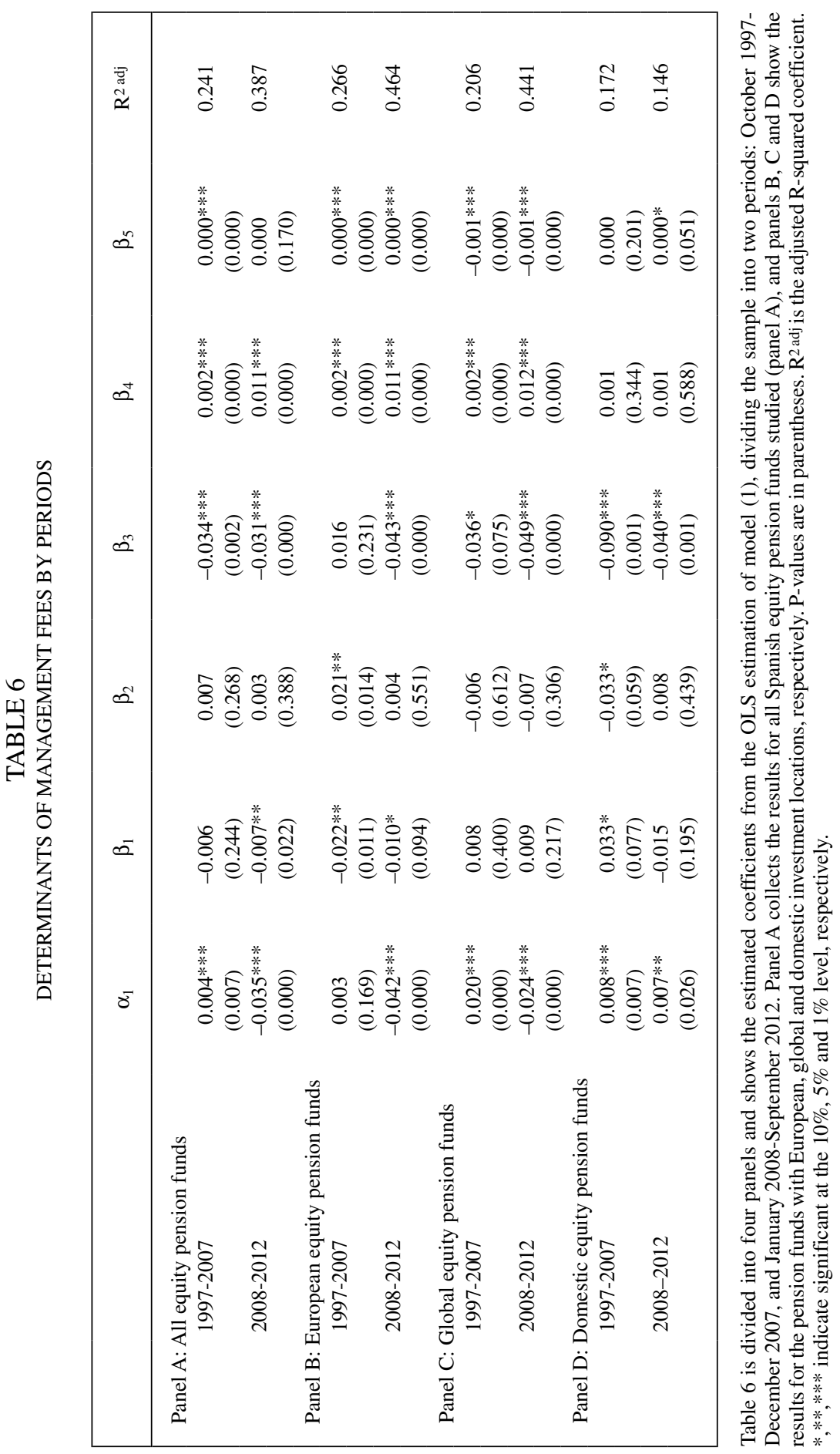




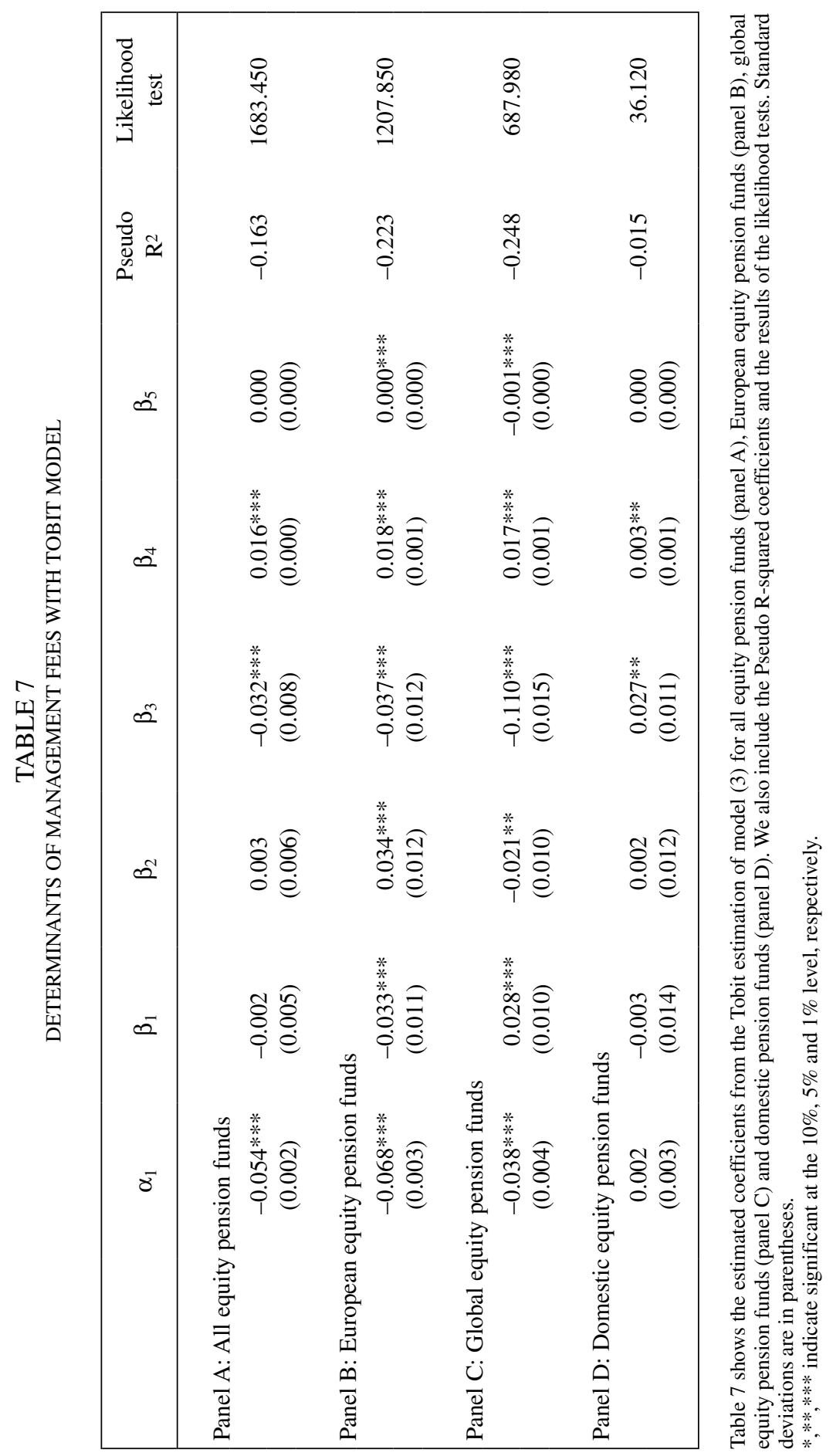


the results display the greatest difference: market return and age are significantly negative, so management fees increase with declining market return, and with younger and larger funds.

Despite these results, our main conclusions do not vary: fund return and market return have no great influence on management fees, and these fees present an inverse relationship to volatility, and a positive influence with size and age.

Finally, we apply a CLAD model, dividing the sample into the two periods, although we do not report these results ${ }^{4}$. With respect to Table 8 , the most notable differences are: returns inversely affect fees in all funds from the period 20082012. Additionally, the fee relationship is significantly negative with fund returns and age, but positive with volatility, in global pension funds from 1997 to 2007.

With this last analysis, we observe a different pattern between the two periods analyzed: fund returns inversely affect management fees only in the period 2008-2012, so fees increase when returns decrease, but rise when returns decline.

\subsubsection{Robustness test of Tobit and CLAD estimations}

Given the differences found in Tobit and CLAD models, we apply the Wald test, collected in expression (5), in order to examine the robustness of both models. Under the null hypothesis, we consider there is no difference between the models.

The statistics reach the following values: 210.1 for all funds, 212.3 for European funds, 62.72 for global funds and 210.4 for domestic pension funds. The critical value is 30.578 at the $1 \%$ significance level, in all cases, leading us to reject the null hypothesis, and indicating that there are significant differences between parametric and semi-parametric models.

In summary, although we do not find great differences between the OLS estimations and censored models, the latter consider the legal limit. Furthermore, there are certain differences between the Tobit and CLAD models, in magnitude and significance level. Specifically, Tobit coefficients are greater in absolute value. Moreover, the Tobit model does not present homoskedasticity and residuals are not normal, so positive coefficients are overestimated and negative coefficients are underestimated. Consequently, the CLAD model presents a better fit since it provides consistent and robust estimators.

\section{Conclusions}

Pension fund investment has increased significantly throughout the world in recent years. Pension fund investors seek good performance, as well as saving for retirement, and obtain the benefits of professional management. Nevertheless, these services come with a cost - the payment of fees.

Other studies have demonstrated negative fee influence on performance, but few works have examined the determinants of fees. In addition, certain countries set legal limits on fees, and, consequently, we should consider estimation models that include these limits, otherwise results could be biased. Censored models

$4 \quad$ These results are available upon request. 


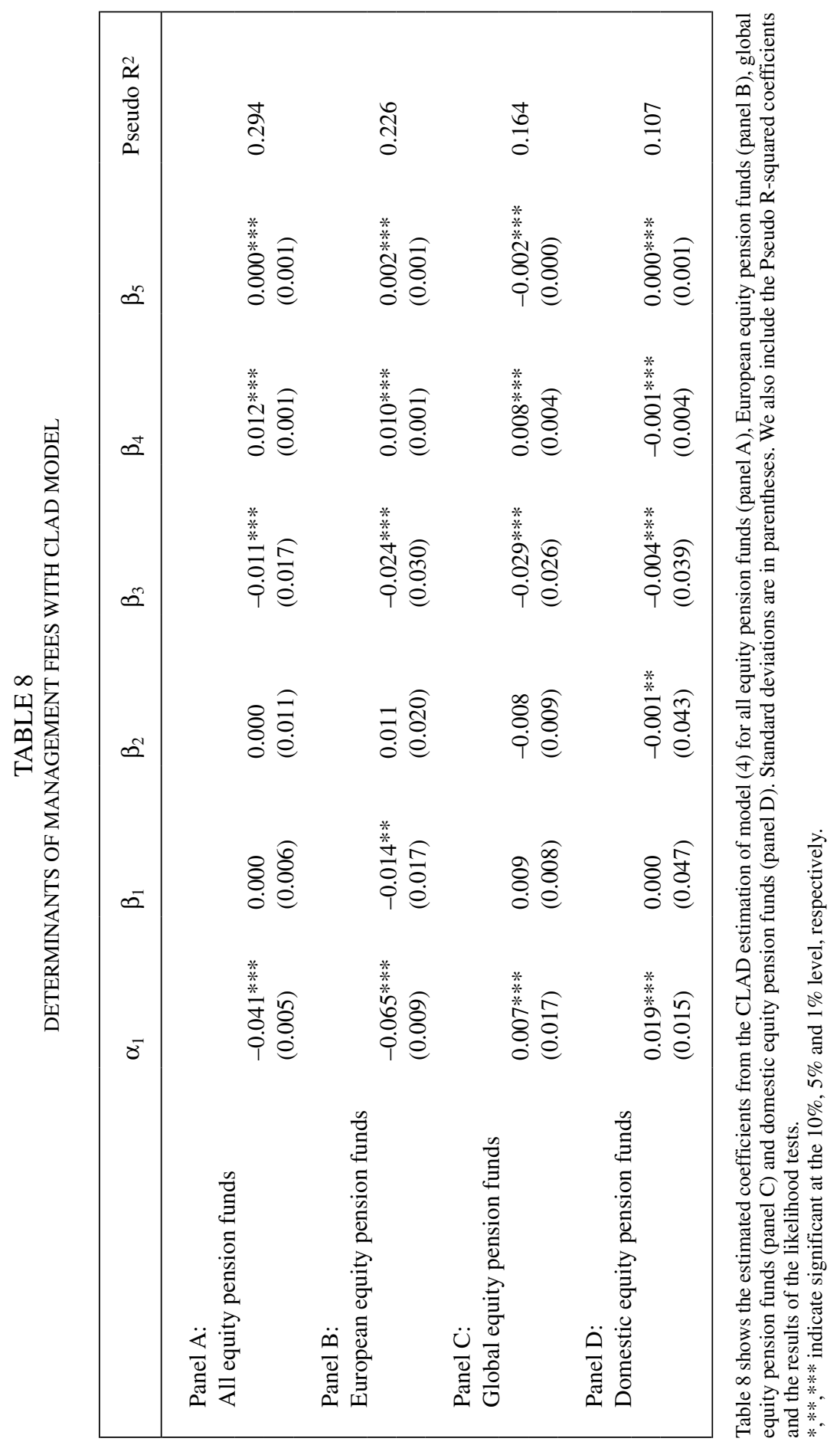


are a good alternative since they consider these limits. In particular, we apply two different models: Tobit and CLAD.

In this work, we study the determining factors of management fees in Spanish equity pension funds, with European, global and domestic investment locations.

The Spanish pension fund market presents some distinctive characteristics. In the first place, all pension funds are private and voluntary. Second, individuals invest in pension plans, but it is the pension fund that does the work. Pension fund assets are actively managed, by professionals, and that is why we focus on pension funds themselves.

Our empirical analysis reveals that OLS estimations produce inconsistent estimators because the model does not take into account the maximum legal limit of fees. Moreover, although the Tobit model considers the limit, we observe heteroskedasticity, and residuals are not normally distributed; in other words, Tobit models provide inconsistent estimators. Finally, the CLAD model generates consistent and robust estimators, providing a better fit.

We find the main determinants of management fees are volatility, age, and size of the pension fund; in particular, pension funds charge higher fees when funds are older and larger, or when volatility is low. On the other hand, the return of a fund, and market returns, do not usually affect fees, although fund returns are more significant in the current period of crisis, showing an inverse relationship to management fees. Nonetheless, these relationships are slightly different when we categorize pension funds according to their investment location (European, global, and domestic).

\section{REFERENCES}

Arabmazar, A. and Schimidt, P. (1981). "Further Evidence on the Robustness of the Tobit Estimator to Heteroskedasticity", Journal of Econometrics, Vol. 17; 253-258.

Blake, D.; Lehmann, B.N. and Timmerman, A. (1999). "Asset allocation dynamics and pension fund performance", Journal of Business, Vol. 72; 429-461.

Blake, D.; Lehmann, B.N. and Timmerman, A. (2002). "Performance clustering and incentives in the UK pension fund industry", Journal of Asset Management, Vol. 3 (2); 173-194.

Brown, S.J.; Goetzmann, W.; Ibbotson, R.G. and Ross, S.A. (1992). "Survivorship bias in performance studies", Review of Financial Studies, Vol. 5 (4); 553-580.

Chou, R.Y. and Cebula, R. (1996). "Determinants of Geographic Differentials in the Savings and Loan Failure Rate- A heteroskedastic Tobit estimation", Journal of Financial Services Research, Vol. 10 (1); 5-25.

Cullinan, C. and Bline, D. (2005). "An analysis of mutual fund custodial fees", The Journal of Applied Business Research, Vol. 21 (1); 13-22.

Deli, D.N. (2002). "Mutual fund advisory contracts: An empirical investigation", Journal of Finance, Vol. 57: 109-133. 
Dellva, W.L. and Olson, G.T. (1998). "The relationship between mutual fund fees and expenses and their effects on performance", The Financial Review, Vol. 33; 85-104.

Dobronogov, A. and Murthi, M. (2005). "Administrative fees and costs of mandatory private pensions in transition economies", Journal of Pension Economics and Finance, Vol. 4 (1); 31-56.

Ferris, S. and Chance M. (1987). "The effect of 12b-1 plans on mutual fund expense ratios: A note", Journal of Finance, Vol. 42; 1077-1082.

Gil-Bazo, J. and Martínez, M.A. (2004). "The Black Box of Mutual Fund Fees", Revista de Economía Financiera, Vol. 4; 54-82.

Golec, J. (2003). "Regulation and the rise in asset-based mutual fund management fees", Journal of Financial Research, Vol. 26 (1); 19-30.

Greene, W.H. (2000). Econometric Analysis. Fourth Edition. Prentice Hall. Englewood Cliffs.

Ippolito, R. and Turner, J. (1987). "Turnover, fees and pension plan performance", Financial Analysts Journal, 43 (6); 16-26.

Khorana, A.; Servaes, H. and Tufano, P. (2009). "Mutual funds fees around the world”, The Review of Financial Studies, Vol. 22 (3); 1279-1310.

Klumpes, P.J.M. and McCrae, M. (1999). "Evaluating the financial performance of pension funds: An individual investor's perspective", Journal of Business Finance and Accounting, Vol. 26 (4); 261-281.

Latzko, D.A. (1999). "Economies of scale in mutual fund administration", Journal of Financial Research, Vol. 22; 331-339.

Loucks, C. (1994). "The regional distribution of bank closings in the United States from 1982 to 1988: A brief note", Southern Economic Journal, Vol. 61 (1); 191-194.

Luo, G. (2002). "Mutual fund fee-setting, market structure and mark-ups", Economica, Vol. 69; 245-271.

Maddala, G. and Nelson, F. (1975). "Specification errors in limited dependent variables models", Working Paper 96. National Bureau of Economic Research. Cambridge.

Malhotra, D. and McLeod R. (1997). "An empirical analysis of mutual fund expenses", Journal of Financial Research, Vol. 20; 175-190.

Martí C. and Matallín J.C. (2008) "Spanish Pension Plans Performance and Persistence." EFMA 2008 Annual Meeting. Available at: http://papers. ssrn.com/sol3/papers.cfm?abstract_id=1100685 [Accessed 2 May 2013]

Martí, C.; Matallín, J.C. and Fernández, M.A. (2007). "Análisis de las variables que determinan las comisiones en los planes de pensiones", Revista de Economía Financiera, Vol. 11; 38-63.

Melenberg, B. and van Soest, A. (1996). "Parametric and semiparametric modeling of vacation expenditures", Journal of Applied Econometrics, Vol. 11 (1); 59-76.

Otten, R. and Bams, D. (2002). "European Mutual Fund Performance”, European Financial Management, Vol. 8 (1); 75-101.

Petersen, D. and Waldman, D. (1981). "The treatment of heteroskedasticity in the limited dependent variable model", Mimeo, University of North Carolina, Chapel Hill.

Powell, J.L. (1984). "Least Absolute Deviations Estimation for the Censored Regression Model”, Journal of Econometrics, Vol. 25 (3); 303-325. 
Sy, W. and Liu, K. (2010). "Improving the Cost Efficiency of Australian Pension Management", Rotman International Journal of Pension Management, Vol. 3 (1); 38-48.

Tobin, J. (1958). "Estimation of Relationships for Limited Dependent Variables", Econometrica, Vol. 26; 24-36.

Tufano, P. and Sevick, M. (1997). "Board structure and fee-setting in the U.S. mutual fund industry”, Journal of Financial Economics, Vol. 46; 321-355.

- Legislation:

Real Decreto 304/2004, de 20 de febrero, por el que se aprueba el Reglamento de Planes y Fondos de Pensiones.

Real Decreto Legislativo 1/2002, de 29 de noviembre, por el que se aprueba el Texto Refundido de Regulación de los Planes y Fondos de Pensiones.

- Websites consulted:

Spanish Association of Pension Plan and Pension Fund Institutions (INVERCO): www.inverco.es

Morgan Stanley Capital International (MSCI): www.msci.com 
